2015 Global Fashion Management Conference at Florence Proceedings: 906-907 (June 2015) http://dx.doi.org/10.15444/GFMC2015.07.01.06

\title{
EXCLUSIVITY VERSUS ACCESSIBILITY: CAN SOCIAL MEDIA REPRESENT AN OPPORTUNITY FOR LUXURY BRANDS IN ITALY?
}

\author{
Gaetano Aiello ,University of Florence, Italy ${ }^{1)}$ \\ Raffaele Donvito ,University of Florence, Italy ${ }^{2)}$ \\ Diletta Acuti, ,University of Florence, Italy ${ }^{3)}$ \\ Valentina Mazzoli ,University of Florence, Italy ${ }^{4)}$
}

\begin{abstract}
In recent years, the spread of social media and other digital tools and its massive acceptance have revolutionized marketing practices such as advertising and promotion (Hanna, Rohn and Crittenden, 2011) by changing the approach of communication between consumers and brands (Henkkig-Thurau et al. 2004) and the sources of information about products, services or brands for consumers (Kozinets, 1999). On the one hand, these changes have provided consumers of the additional power to influence other buyers by sharing ideas and experiences about products, services or brands (Ioanăs \& Stoica 2014). On the other hand social media websites allow business to engage and interact with users by increasing sense of intimacy with consumers and building strong relationships with potential customers (Mersey et al. 2010). Therefore, the incomparable efficiency of social media has induced industry leaders to participate in Facebook, Twitter, Instagram and others, with the aim to succeed in online environments (Kaplan and Haenlein 2010). Furthermore, brands are motivated to develop social network campaigns for gathering consumers' personal information useful to targeting or personalising future marketing strategies (Noort, Anthenius and Verlegh, 2014). This situation have brought many authors, especially interested in luxury industry, to investigate on social media as a new way for luxury firms to communicate with consumers and influence their purchases. One of the main objectives for literature was to understand if luxury products, related to prestige, uniqueness and exclusivity values, could be express using channels accessible to everyone, such as social media. Indeed, in this era of the "democratization of luxury" (Atwal and Williams 2009), luxury brands are dealing with the challenge of using mass marketing tools and at the same time emphasizing the exclusivity dimension of their products (Okonkwo 2010). So as Hennigs states: "As the virtual environment is a place where images, videos and opinions circulate regardless of brand ownership, is it possible to keep a sense of exclusivity around a luxury brand?" (Hennigs, Wiedmann and Klarmann 2012 p. 30). In Italy, the digital population keep growing and the time spent in front of digital devices is increasing; people is becoming more familiar with e-commerce and as a consequence the

\footnotetext{
1) gaetano.aiello@unifi.it

2) raffaele.donvito@unifi.it

3) diletta.acuti@unifi.it

4) mazzoli1.valentina@gmail.com
} 
communication of firms is more transparent (The Boston Consulting Group 2011). In this perspective, this paper aims to analyse the impact of social media marketing on brand equity and consumer behaviour within the Italian luxury economy. Our research has tried to understand this phenomenon from two perspectives; on the one hand, authors have observed digital marketing strategies of some luxury firms, emphasizing the way these brands use social network to promote their products, their special events or their stories. On the other hand, researchers have studied consumers' approaches to social networks through a survey (Chisnall 1993) delivered to a sample of Italian respondents. The goal

of the research is to show how social media have been used by five luxury brands and how they can influence luxury brand equity, by affecting Italian consumer behaviour. With this objective, the authors have analysed the composition of the sample that is active on social networks in order to gather useful demographic information about users. Moreover, this research has been important to discover the most popular platforms for Italian users and the response of some of the major international luxury brands in terms of contents shared on specific social networks. In addition, the survey has represented a great opportunity to understand the influence of social network on consumer behaviour, seeking to measure cognitive, affective and conative responses (Laroche and Mourali 005).

Keywords: social media, luxury brand, Italy, marketing, network

\section{References available upon request}

